\title{
Стадійність управління персоналом у сучасних умовах господарювання
}

\author{
(Представлено: д.е.н., проф. Калініченко Л.Л.)
}

У статті проаналізовано стадії управління персоналом: планування персоналу, підбір та відбір, адаптаџія, розвиток, оцінка та атестація. Сутність такої стадї, як планування персоналу розкрито із застосуванням методів, таких як: метод експертних оцінок, нормативний метод, балансовий метод, математико-статистичний метод та метод екстраполячії. Щодо стадії підбір та відбір персоналу. То підбір персоналу означено як процес проходження шести етапів: визначення потреби в нових працівниках; визначення вимог до кандидата; пошук $і$ залучення кандидатів на вакантну посаду; збір інформачії про кандидатів; оиінювання кандидатів на вакантну посаду; прийняття рішення про заповнення вакансії, а як результат прачевлаштування та ознайомлення з посадою. Щодо відбору персоналу пропонується ряд методів, щуо поділяються на традиійні та нетрадиційні, традиційні методи включають: співбесіду, анкетування, центри очінки, тестування, резюме; нетрадиційні методи, в свою чергу, включають: фізіогноміку, сочіоніку, графологію, вивчення відбитків пальців, шокове інтерв'ю, вrainteaser-інтерв'ю, які згруповано в схематичне зображення. Адаптацію персоналу умовно поділено на чотири етапи. Перший етап - оцінювання рівня підготовленості новачка, другий етап - орієнтація, третій етап - безпосередня адаптація, четвертий етап функціонування. Автори наголосили, щцо стадія розвитку персоналу будується иляхом через особисте зростання працівників $i$ до підвищення ефективності виробнищтва. Щодо стадіi оцінка та атестація персоналу, то оцінка персоналу викладена як аналіз ефективності працівника на даному робочому місиі за певний період часу, перевірка відповідності стандартам виконання роботи згідно з заданими критеріями. Результати оцінки важливі для визначення «зон найближчого розвитку», а також отримання орієнтирів для подальшого управління досягненнями персоналу, коли атестаџія персоналу як прочедура систематичної формалізованоі оцінки відповідності рівня праці, якостей $і$ потенціалу особистості співробітників вимогам виконуваної роботи. Атестація дозволяе отримати інформацію для прийняття подальших управлінських рішень, за якими сформовано класифікацію за умови послідовного та повного проходження всіх стадій управління персоналом.

Ключові слова: управління персоналом; стадії; планування; відбір; адаптація; розвиток; aтестація.

Актуальність теми. На сьогодні перетворення в системі економіки вимагають значних трансформацій у відношеннях роботодавець-працівник. Насамперед така ситуація складається через те, що людина в соціально-економічних процесах набуває дедалі більшого значення, тому процес управління персоналом має бути сформований таким чином, щоб мати змогу підвищити конкурентоспроможність вітчизняних підприємств в умовах глобалізації, що свідчить про актуальність даного дослідження.

Аналіз останніх досліджень і публікацій. Дослідженню управління персоналом присвячено наукові праці таких вчених, як В.В. Смачило, Л.Л. Калініченко, О.М. Чупир, І.В. Стояненко, Я.В. Дерунець, Н.І. Ссінова, О.І. Зайченко, В.І. Кузнецова, В.В. Колеснікова.

Мета дослідження. Існуюча модель стадійності управління персоналом в сучасних умовах розвитку та євроінтеграції економічної ситуації та держави в цілому є не досить досконалою, що обумовлює поглиблене вивчення цього направлення, а саме: аналіз та розмежування існуючих стадій управління персоналом, визначення їх складових та обгрунтування управлінських рішень.

Викладення основного матеріалу. Управління персоналом має повністю узгоджуватись із концепцією розвитку організації і передбачає такі стадії управління персоналом:

1. Планування персоналу;

2. Підбір і відбір персоналу;

3. Адаптація персоналу;

4. Розвиток персоналу;

5. Оцінка персоналу, атестація. 
Планування персоналу - елемент загальної системи планування підприємства, в межах якого вирішуються завдання забезпечення ii робочою силою необхідної кількості та якості, а також вдосконалення соціальних відносин [1].

Дядечко Л.П. [2] рекомендує при плануванні чисельності працівників будь-якого підприємства виходити з руху кадрів, розраховувати як суму чисельності працівників відповідно на початок періоду, прийнятих, звільнених і на кінець періоду.

Загальними етапами планування кадрів підприємства будь-якої сфери діяльності є такі:

1) визначення очікуваної чисельності працівників на початок планового періоду;

2) розрахунок потреби в працівниках для виконання планового обсягу робіт;

3) обгрунтування (прогнозування) вибуття працівників у плановому періоді;

4) розрахунок поповнення працівників, необхідного для забезпечення планових обсягів діяльності.

3 урахуванням якісних характеристик чисельність персоналу планується на основі таких передумов:

- штатного розпису підприємства, де наводиться перелік посад;

- вимог до посад і робочих місць, закріплених посадовими інструкціями або характеристиками робочих місць;

- документації, яка регламентує процеси діяльності 3 виділенням вимог до професійнокваліфікаційного складу виконавців.

Розрахунки потреби в кадрах за професіями, спеціальностями тощо передбачають визначення кількості персоналу за кожним критерієм якості. Метод такого планування називається нормативним. Розрахунки ведуться окремо по кожній категорії працівників за видом діяльності. Загальна потреба в персоналі визначається підсумовуванням кількісної потреби в кожній категорії працівників.

Чисельність основних працівників (обслуговуючого персоналу) визначається на основі розроблених кожним підприємством своїх нормативів. Установлені нормативи використовуються при розрахунку явочної чисельності працівників, що забезпечує безперервність роботи підприємства. Для кожної групи обслуговуючого персоналу установлюється зона (норма) обслуговування.

За наявності таких норм явочна чисельність працівників при однозмінній роботі визначається діленням кількості обслуговуваних місць (зона обслуговування) підприємства на норму обслуговування місць одним працівником.

При незмінному режимі роботи підприємства явочна чисельність працівників, які обслуговують робочі місця, може розраховуватися за даними одного тижня, якщо розрахувати добуток кількості робочих місць на підприємстві, кількість робочих змін, тривалість зміни в годинах, кількість робочих днів за тиждень поділений на тривалість робочого тижня одного явочного працівника в годинах.

Після розрахунків чисельності основних працівників на плановий період визначається середньооблікова чисельність адміністративно-управлінського персоналу. При плануванні чисельності цього персоналу використовується метод прямих розрахунків.

При плануванні кількості фахівців застосовуються нормативні коефіцієнти насичення кадрів фахівцями. Потреба у фахівцях при цьому розраховується як добуток облікової чисельності та нормативного коефіцієнта насичення персоналу фахівцями.

Планування персоналу здійснюється за допомогою методів. Більш застосовуваними методами планування персоналу є:

- метод експертних оцінок, що базується на використанні думок спеціалістів для визначення необхідності персоналу [3];

- нормативний метод - врівноваження наявних ресурсів та потреби в них у плановому періоді, включає планову та додаткову потребу в працівниках на початок і кінець періоду [4];

- балансовий метод - заснований на взаємозв'язку існуючих і необхідних ресурсів, тобто коли існує нестача робочої сили, відбувається пошук нових співробітників [5];

- математико-статистичний метод грунтується на оптимізаційних розрахунках та розробці різних моделей (статистичних, кореляційних тощо.) [6];

- метод екстраполяції перенесення сьогоднішньої ситуації (пропорцій) в майбутнє. Метод підходить для короткострокового планування і для організацій зі стабільною структурою, діючих в стабільному зовнішньому середовищі [3].

Після планування персоналу наступає друга стадія управління персоналом - підбір та відбір персоналу.

Веснін В.Р. [7] вважає, що підбір персоналу є процесом вивчення психологічних та професійних якостей працівника $з$ метою направлення його на виконання обов'язків на певному робочому місці або посаді та вибору із сукупності претендентів найбільш підходящого з урахуванням відповідності його кваліфікації, спеціальності, особистісних якостей та здібностей характеру діяльності.

Підбір персоналу здійснюється за рахунок проходження етапів, що наведені на рисунку 1. 
Етапи підбору персоналу

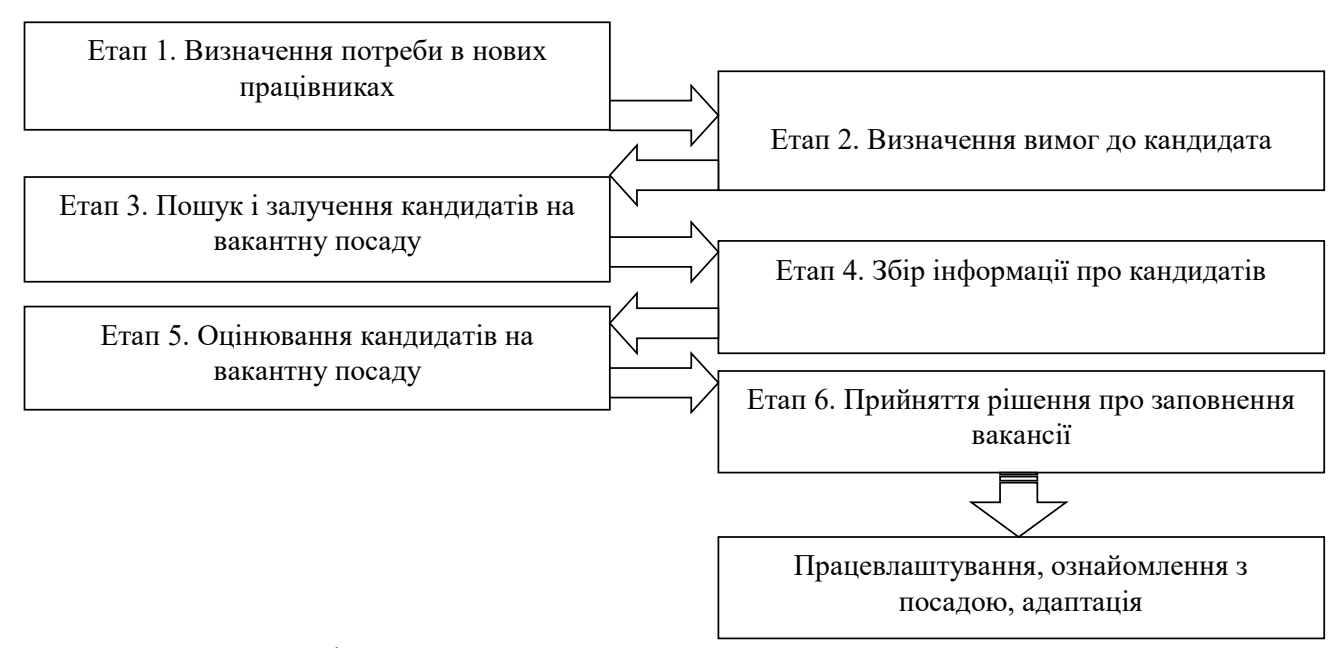

Примітка: складено авторами на основі джерела [8]

Рис. 1. Етапи підбору персоналу

Автори підтримують думку В.А. Свтушенко, М.М. Кудінової, К.О. Лазарєвої [11], які пропонують ряд методів відбору персоналу, що поділяються на традиційні та нетрадиційні (рис. 2).

Традиційні методи відбору персоналу:

- співбесіда - являє собою обмін інформацією між уповноваженим представником або кадровою комісією організації і претендентом на зайняття вакантної посади, що дозволяє вирішити основні питання професійного відбору [9];

- анкетування - $є$ обов'язковою процедурою прийняття на будь-яку роботу, за фахом чи ні. Анкета заповнюється опитуваним самостійно, тому іï конструкція і всі коментарі мають бути чіткими лаконічними та легко зрозумілими для респондента [10];

- центри оцінки - цей метод являє собою вид тренінг-гри, у якій претендент знаходиться в ситуації, максимально наближеній до робочої обстановки і під час гри кандидата просять висказати свою думку 3 приводу всього процесу чи проаналізувати якусь його частину [11];

- тестування. Тести, використовувані при прийомі на роботу, в основному являють собою набори завдань, призначені для виявлення рівня інтелекту або властивостей особистості, ставлення людини до тих чи інших ситуацій, що дає можливість виявити його професійні схильності, вміння бути лідером і працювати з людьми, перевірити якісь професійні навички або здібності до навчання [12, с. 37-39];

- резюме - опис професійної діяльності. Один з найефективніших інструментів пошуку роботи. Воно $\epsilon$ коротким викладом найбільш важливих для потенційного працедавця фактів біографії претендента, в основному пов'язаних з досвідом роботи, навичками та знаннями [13].

Нетрадиційні методи відбору персоналу:

- $\quad$ фізіогноміка - частіше за все використовується як допоміжний метод. Сутність методу в тому, щоб вивчити риси обличчя людини та міміку. На основі отриманих даних робиться висновок про тип особистості людини, здатність людини до аналізу та творчі здібності [14, с. 73];

- метод соціоніки. Згідно з цією наукою, існує 16 типів сприйняття та обробки інформації, що відповідають 16 соціотипам людей, які поводяться однаково в тій самій ситуації, тому що в них збігаються мотиви, що підштовхують їх до прийняття рішення. Ця методика достовірна лише на $80 \%$. Через це цей метод відбору персоналу не є дуже розповсюдженим [15, с. 164];

- графологія - найменш розвинений метод у країнах пострадянського простору. Під час вивчення беруться до уваги натиск, обриси, нахил букв, гострота букв та інші деталі. На основі цих даних визначається, який характер притаманний людині [16, с. 82].

вивчення відбитків пальців також не розповсюджений метод у країнах пострадянського простору. Цей метод являє собою аналіз рисунка на пальці людини. Такий аналіз допомагає визначити характер людини. Окрім того, існує ще й думка про те, що кількість завитків на цьому рисунку $є$ свідоцтвом коефіцієнта розуму людини [16, с. 82];

шокове інтерв'ю нині широко використовується, особливо у великих компаніях та на посадах, які потребують стресостійкості. За такого виду відбору персоналу завдання HR-менеджера чи рекрутера - створити стресові умови для претендента та проаналізувати реакцію та поведінку кандидата у стресовій ситуації $[17$, с. 106$]$; 
- $\quad$ вrainteaser-інтерв'ю зазвичай використовують у сферах, де необхідно проявляти кмітливість, харизму та винахідливість, здібність аналітично мислити. Кандидату пропонують вирішити завдання на логіку, або менеджер задає питання, що не стосується теми розмови. Цей метод переважно використовують вітчизняні представництва зарубіжних компаній [14, с. 73].

Ознайомившись з обома методами відбору персоналу, можемо дати характеристику даним методам (рис. 2).

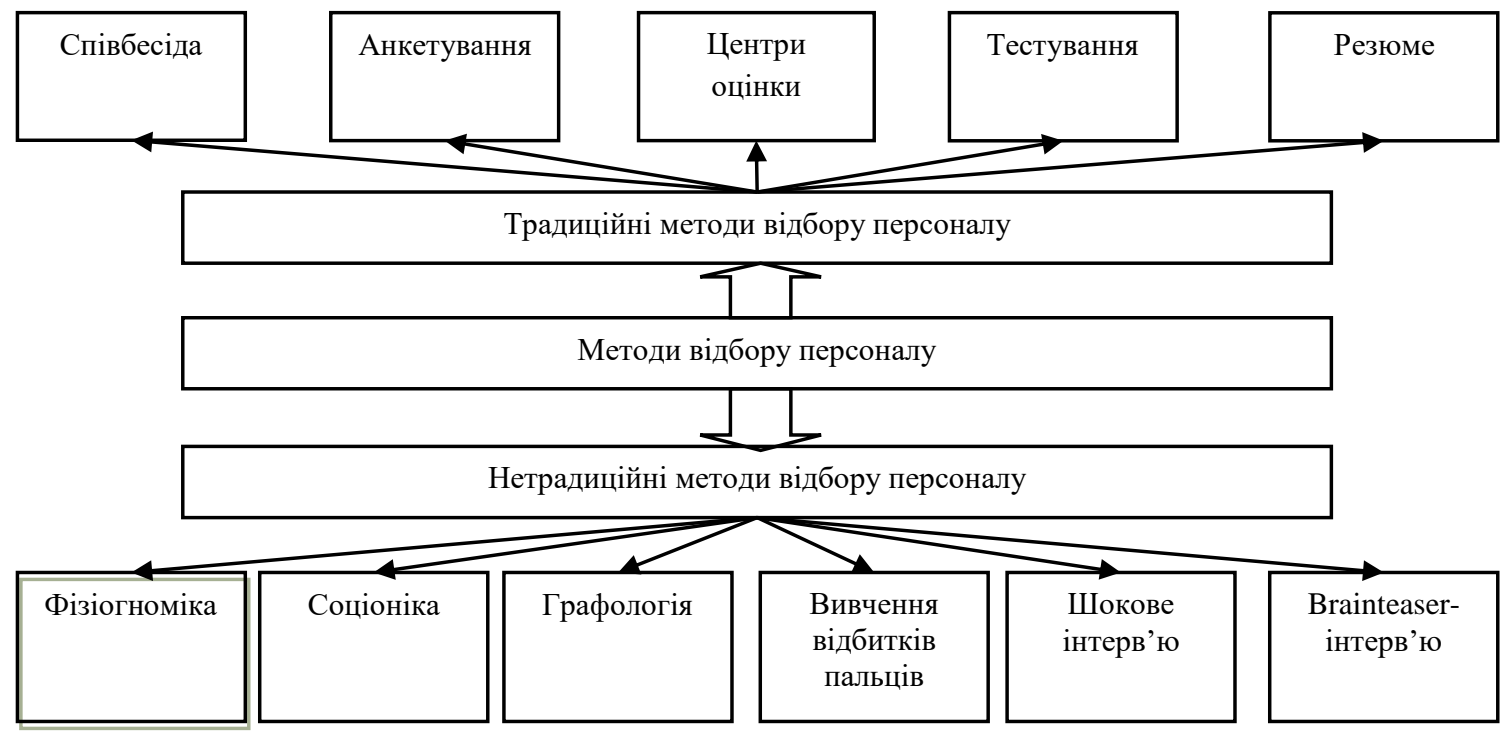

Примітка: побудовано авторами на основі джерел [11-16]

\section{Рис. 2. Методи відбору персоналу}

Після відбору персоналу та зайняття ним своїх посад наступає стадія адаптації персоналу.

Автори зауважують, що адаптація персоналу - це процес пристосування працівника до правил та вимог, які висуваються до посади, яку він займає та розпорядку організації.

Автори підтримують думку В.В. Колеснікової [18], яка наголошує, що процес адаптації умовно можна поділити на чотири етапи (рис. 3).

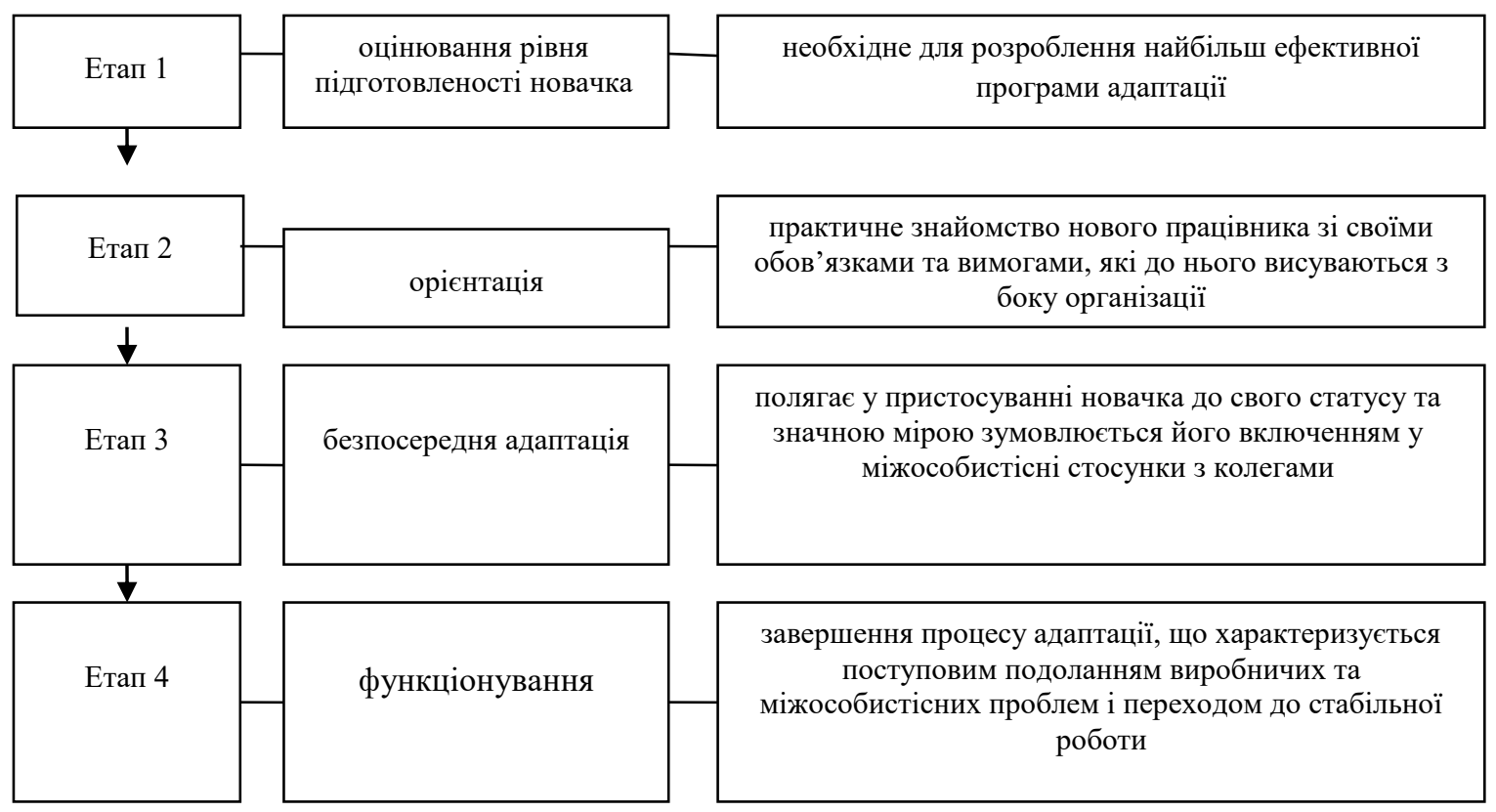

Примітка: сформовано авторами на основі джерела [18]

Рис. 3. Проиес адаптації персоналу 
Після проходження процесу адаптації працівник переходить до наступної стадії - стадії розвитку.

За словами I.I. Грибик, Г.Р. Копець [19], розвиток персоналу - це система навчання, організаційного розвитку та професійного зростання персоналу, функціонування якої спрямовано на вирішення поточних і стратегічних завдань організації завдяки забезпеченню більшої індивідуальної та організаційної ефективності.

Основна мета розвитку персоналу - збільшення «віддачі» кожного працівника, структурного підрозділу та організації в цілому. Система розвитку персоналу передбачає: професійне навчання; планування та розвиток кар'єри; створення та ведення кадрового резерву; розкриття потенціалу працівників, найефективніше використання їхніх здібностей, знань і навичок.

3 наведених вище визначень можна зробити висновок, що розвиток персоналу впливає не лише на особисте зростання працівників, але і, як наслідок, на підвищення ефективності виробництва.

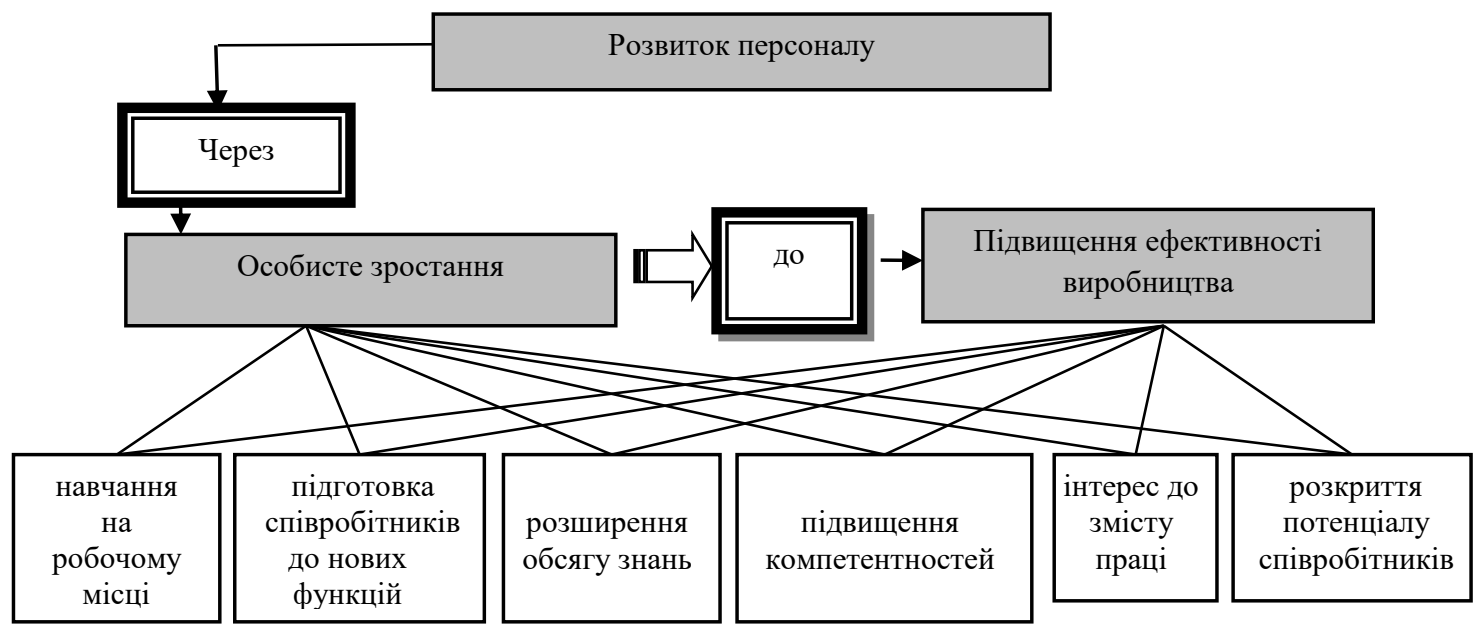

Примітка: побудовано авторами на основі [19]

Рис. 4. Розвиток персоналу підприємства

На наступному етапі управління персоналом відбувається оцінювання та атестація персоналу.

Оцінка персоналу - це аналіз ефективності працівника на даному робочому місці за певний період часу, перевірка відповідності стандартам виконання роботи згідно з заданими критеріями. Результати оцінки важливі для визначення «зон найближчого розвитку», а також отримання орієнтирів для подальшого управління досягненнями персоналу [20, с. 147].

Атестація персоналу - це процедура систематичної формалізованої оцінки відповідності рівня праці, якостей і потенціалу особистості співробітників вимогам виконуваної роботи. Атестація дозволяє отримати інформацію для прийняття подальших управлінських рішень [20, с. 147].

На основі результатів оцінювання грунтується ряд різних управлінських рішень (рис. 5) за такою класифікацією:

- за умови порушень трудової дисципліни, невиконання доручень керівництва;

- за умови якісного виконання роботи;

- за виробничої необхідності.

Проаналізувавши етапи управління персоналом, можна зробити висновок, що проходження всіх стадій є обов'язковою умовою для трудової діяльності кожного працівника, а також необхідним $є$ послідовність проходження стадій управління персоналом (рис. 5). 


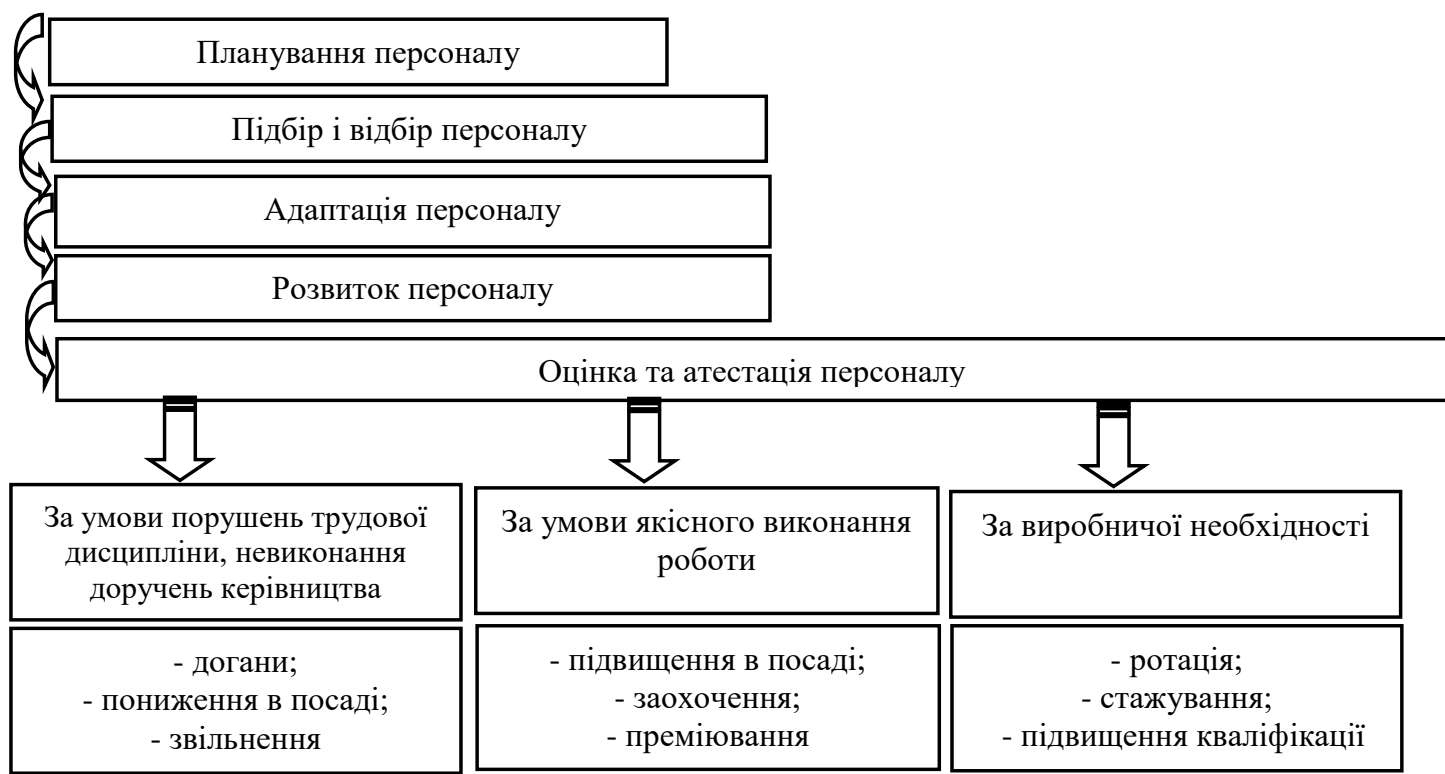

Примітка: побудовано авторами на основі власних досліджень

\section{Рис. 5. Стадії управління персоналом}

Висновки та перспективи подальших досліджень. Проходження стадій управління персоналом $\epsilon$ необхідним для кожного працівника, а також обов'язковою умовою $є$ послідовність проходження усіх стадій. На основі проведених досліджень щодо стадій управління персоналом авторами сформовано класифікацію управлінських рішень, які приймаються керівництвом стосовно кожного працівника після проходження ним всіх наведених стадій управління.

До перспектив подальших досліджень можна зарахувати трансформацію методів відбору персоналу, навчання та розвитку, а також, як результат, класифікацію управлінських рішень, які матимуть змогу відповідати сучасним науково-економічним вимогам.

Список використаної літератури:

1. Короткий курс лекцій з дисципліни «Економіка підприємства» [Електронний ресурс]. - Режим доступу : https://studme.com.ua/16801028/ekonomika/etapy_protsessa_upravleniya_personalom_predpriyatiya.htm.

2. Дядечко Л.П. Економіка туристичного бізнесу : навч. посібник / Л.П. Дядечко. - К. : Центр учбової літератури, 2007. - 224 с.

3. Ларка M.I. Персонал підприємства та методи його планування / M.I. Ларка, О.С. Бондаренко // Вісник НТУ «ХПІ». - 2013. - № 22 (995). - С. 7-13.

4. Чумаченко О.В. Особливості планування управлінського персоналу / О.В. Чумаченко, Т.С. Шульгіна [Електронний ресурс]. - Режим доступу http://ea.donntu.org:8080/jspui/bitstream/123456789/14034/1/2.\%20\%D0\%9E\%D0\%A1\%D0\%9E\%D0\%91\%D0\%9B\% D0\%98\%D0\%92\%D0\%9E\%D0\%A1\%D0\%A2\%D0\%86\%20\%D0\%9F\%D0\%9B\%D0\%90\%D0\%9D\%D0\%A3\%D0\% 92\%D0\%90\%D0\%9D\%D0\%9D\%D0\%AF\%20\%28\%D0\%94\%D0\%BD\%D0\%B5\%D0\%BF\%D1\%80\%29.pdf.

5. Гери М.В. Планирование персонала / M.В. Гери [Електронний ресурс] - Режим доступу : http://lexandbusiness.ru/view-article.php?id=4256.

6. Михайлова Л.І. Управління персоналом : навч. посібник / Л.І. Михайлова. - К. : Центр учбової літератури, 2007. $-248 \mathrm{c}$

7. Веснин В.P. Управление персоналом. Теория и практика : учебник / В.P. Веснин. - М. : Проспект, 2009. - 134 с.

8. Павленко К.О. Сучасні технології підбору персоналу / К.О. Павленко, Т.С. Шульгіна // Науковий вісник Херсонського державного університету. - 2017. - Вип. 23. - Ч. 3. - С. 30-33.

9. Калінін А.М. Особливості проведення співбесіди як методу професійного відбору персоналу в ринкових умовах / А.M. Калінін // Наукові праці Кіровоградського національного технічного університету. Економічні науки. - 2014. - № 26. - С. 91-97.

10. Никифоров А.M. Анкетування та тестування як процедури прийняття на роботу творчої молоді / А.М. Никифоров // Молодий вчений. - листопад 2016 р. - № 11.1 (38.1). - С. 73-76.

11. Свтушенко B.A. Інноваційні методи відбору персоналу в сучасних умовах / B.A. Євтушенко, М.M. Кудінова, К.О. Лазарєва [Електронний ресурс]. - Режим доступу : http://www.easterneuropeebm.in.ua/journal/8_2017/30.pdf.

12. Григор'єва O.B. Чинники успішного працевлаштування за фахом : навч. посіб. для студ. напрямів підготовки 030504 «Економіка підприємства» і 6.030505 «Управління персоналом та економіка праці»/ О.В. Григор'єва, Т.О. Галайда. - Полтава : ПолтНТУ, 2015. - 97 с.

13. Давидова I.O. Чинники успішного працевлаштування за фахом : навч.-метод. посіб. для студ. напряму підготовки 0305 «Економіка та підприємництво» / I.О. Давидова. - Х. : ХДУХТ, 2015. - 100 с. 
14. Воронкова В.Г. Управління людськими ресурсами: філософські засади : навч. посібник / В.Г. Воронкова, А.Г. Беліченко, О.М. Попов. - К. : Професіонал, 2006. -576 с.

15. Іванова С. Мистецтво підбору персоналу. Як оцінити людину за годину / С.Іванова. - К. : Альпіна бізнес букс, 2004. - $160 \mathrm{c.}$

16. Колот А.М. Соціально-трудові відносини: теорія і практика регулювання : монографія / А.М. Колот. - К. : Кнеу, 2005. - $230 \mathrm{c}$.

17. Балабанова Л.В. Управління персоналом / Л.В. Балабанова, О.В. Сардак. - К. : Центр учбової літератури, 2009. $-463 \mathrm{c}$.

18. Колеснікова В.В. Удосконалення системи управління процесом адаптації персоналу шляхом застосування інноваційних підходів / В.В. Колеснікова // Теорія та практика державного управління. - 2018. - № 1 (60) [Електронний ресурс]. - Режим доступу : http://www.kbuapa.kharkov.ua/e-book/tpdu/2018-1/doc/4/03.pdf.

19. Грибик I.I. Проблеми розвитку персоналу на вітчизняних підприємствах / I.I. Грибик, Г.P. Копеиь [Електронний ресурc]. - Режим доступу : http://ena.lp.edu.ua/bitstream/ntb/2443/1/37.pdf.

20. Кузь А.О. Мотивуюча роль оцінки персоналу : за матеріалами міжнар. наук.-практ. інтернет-конференції «Формування конкурентоспроможної економіки: теоретичні, методичні та практичні засади» / А.О. Кузь , M.I. Зелена. - Тернопіль, 2012. - С. 147-148.

21. Смачило В.В. Ідентифікація соціально-економічної категорії «персонал підприємства» / В.В. Смачило, Т.Л. Наливайко / Економіка, управління та адміністрування. - 2019. - № 3 (89). - С. 47-56.

\section{References:}

1. Korotkyj kurs lekcij z dyscypliny «Ekonomika pidpryjemstva», [Online], available at: https://studme.com.ua/16801028/ekonomika/etapy_protsessa_upravleniya_personalom_predpriyatiya.htm

2. Djadechko, L.P. (2007), Ekonomika turystychnogo biznesu, Centr uchbovoi' literatury, Kyiv, 224 p.

3. Larka, M.I. and Bondarenko, O.S. (2013), «Personal pidpryjemstva ta metody jogo planuvannj», Visnyk NTU «HPI», Vol. 22, pp. 7-13.

4. Chumachenko, O.V. and Shul'gina, T.S. (2011), Osoblyvosti planuvannja upravlins'kogo personalu, Vol. 1 (23), pp. 186-190.

5. Gersh, M.V. (2014), Planirovanie personala, [Online], available at: http://lexandbusiness.ru/viewarticle.php?id=4256

6. Myhajlova, M.V. (2007), Upravlinnja personalom, Centr uchbovoi' literatury, Kyiv, 248 p.

7. Vesnin, V.R. (2009), Upravlenie personalom. Teoriya i praktika, Prospekt, Moskva, 134 p.

8. Pavlenko, K.O. and Shul'gina, T.S. (2017), «Suchasni tehnologii' pidboru personal», Naukovyj visnyk Hersons'kogo derzhavnogo universytetu, Vol. 23, pp. 30-33.

9. Kalinin, A.M. (2014), «Osoblyvosti provedennja spivbesidy jak metodu profesijnogo vidboru personalu v rynkovyh umovah», Naukovi praci Kirovograds'kogo nacional'nogo tehnichnogo universytetu. Ekonomichni nauky, Vol. 26, pp. 91-97.

10. Nykyforov, A.M. (2016), «Anketuvannja ta testuvannja jak procedury pryjnjattja na robotu tvorchoi' molodi», Molodyj vchenyj, Vol. 11.1 (38.1), pp. 73-76.

11. Jevtushenko, V.A., Kudinova, M.M. and Lazarjeva, K.O. (2017), Innovacijni metody vidboru personalu v suchasnyh umovah, [Online], available at: http://www.easterneurope-ebm.in.ua/journal/8_2017/30.pdf

12. Grygor'jeva, O.V. and Galajda, T.O. (2015), «Chynnyky uspishnogo pracevlashtuvannja za fahom», Poltavskii nationalnii tekhnichnii universitet imeni Yuriia Kondratiuka, PoltNTU, Poltava, $97 \mathrm{p}$.

13. Davydova, I.O. (2015), Chynnyky uspishnogo pracevlashtuvannja za fahom, HDUHT, Harkiv, 100 p.

14. Voronkova, V.G., Belichenko, A.G. and Popov, O.M. (2006), Upravlinnja ljuds'kymy resursamy: filosofs'ki zasady, Profesional, Kyiv, $576 \mathrm{p}$

15. Ivanova, S. (2004), Mystectvo pidboru personalu. Jak ocinyty ljudynu za godynu, Al'pina biznes buks. Kyiv, 160 p

16. Kolot, A.M. (2005), Social'no-trudovi vidnosyny: teorija i praktyka reguljuvannja, KNEU, Kyiv, 230 p.

17. Balabanova, L.V. and Sardak, O.V. (2009), Upravlinnja personalom, Centr uchbovoi' literatury, Kyiv, 463 p.

18. Kolesnikova, V.V. (2018), «Udoskonalennja systemy upravlinnja procesom adaptacii' personalu shljahom zastosuvannja innovacijnyh pidhodiv», Teorija ta praktyka derzhavnogo upravlinnja, Vol. 1 (60), [Online], available at: pp. 1-7, http://www.kbuapa.kharkov.ua/e-book/tpdu/2018-1/doc/4/03.pdf

19. Grybyk, I.I. and Kopec', G.R. (2009), Problemy rozvytku personalu na vitchyznjanyh pidpryjemstvah, [Online], available at: http://ena.lp.edu.ua/bitstream/ntb/2443/1/37.pdf

20. Kuz', A.O. and Zelena, M.I. (2012), «Motyvujucha rol' ocinky personal», Mizhn. nauk.-prakt. internet-konferencija «Formuvannja konkurentospromozhnoi' ekonomiky: teoretychni, metodychni ta praktychni zasady», Ternopil', pp. 147-148.

21. Smachylo, V.V. and Nalyvajko, T.L. (2019), «Identyfikacija social'no-ekonomichnoi' kategorii' «personal pidpryjemstva», Ekonomika, upravlinnja ta administruvannja, No. 3 (89), pp. 47-56.

Устіловська Анастасія Сергї̈вна - аспірант, викладач кафедри економіки Харківського національного університету будівництва та архітектури.

Orcid.org/0000-0002-9297-7614

Наукові інтереси:

управління персоналом; економіка праці та підприємства; економіка будівництва, підприємництво.

Безрук Світлана Олегівна - магістрант кафедри економіки Харківського національного університету будівництва та архітектури.

Orcid.org/0000-0003-3251-4631

Наукові інтереси: управління персоналом; економіка праці та підприємства.

Стаття надійшла до редакції 20.11.2019. 